\title{
COVER ART
}

Carmen Mason (cover photo) is a junior at American University majoring in Film and Media Arts with a minor in Anthropology. She has a passion for all things related to media and design, and invests a large portion of her time on social justice issues and community organizing. In the future, she hopes to find a career where she can integrate all of her loves and passions into one.

Carla Mavaddat (cover design) is an undergraduate majoring in Political Science at McGill University with a passion for photography and design. She is originally from Montreal, Canada but grew up in Washington (D.C.). Carla is interested in human rights and social justice, and is a strong advocate against poverty. Her photos have appeared in Adore Noir, among other venues. She is the graphics and design editor for BleakHouse Review and curator for BleakHouse Publishing.

Cover: "Untitled"

The cover photo was taken by Carmen Mason in Washington (D.C.) on a cold winter's day and woven into the cover design by Carla Mavaddat to capture the isolation of penal confinement. The cover is meant to capture an outsider's view of the world through the fence, which is frozen over, adding an element of symbolic isolation and distance - a cold boundary that, like a prison wall or fence, demarcates the free world and the world of confinement, with the persons behind the barrier able to see but not touch or enter the outside world. 